Journal of Southeast Asian

\title{
The Model Minority Stereotype as a Prescribed Guideline of Empire: Situating the Model Minority Research in the Postcolonial Context
}

Eun Hee Kim

Kansas State University, eunheek@ksu.edu

Kay Ann Taylor

Kansas State University, ktaylor@ksu.edu

50 Years of Model Minority Stereotype Research

Dr. Nicholas Hartlep

Metropolitan State University

Follow this and additional works at: https://docs.lib.purdue.edu/jsaaea

Part of the Bilingual, Multilingual, and Multicultural Education Commons

\section{Recommended Citation}

Kim, Eun Hee and Taylor, Kay Ann (2017) "The Model Minority Stereotype as a Prescribed Guideline of Empire: Situating the Model Minority Research in the Postcolonial Context," Journal of Southeast Asian American Education and Advancement. Vol. 12 : Iss. 2, Article 4.

DOI: $10.7771 / 2153-8999.1156$

Available at: https://docs.lib.purdue.edu/jsaaea/vol12/iss2/4

This document has been made available through Purdue e-Pubs, a service of the Purdue University Libraries.

Please contact epubs@purdue.edu for additional information.

This is an Open Access journal. This means that it uses a funding model that does not charge readers or their institutions for access. Readers may freely read, download, copy, distribute, print, search, or link to the full texts of articles. This journal is covered under the CC BY-NC-ND license. 


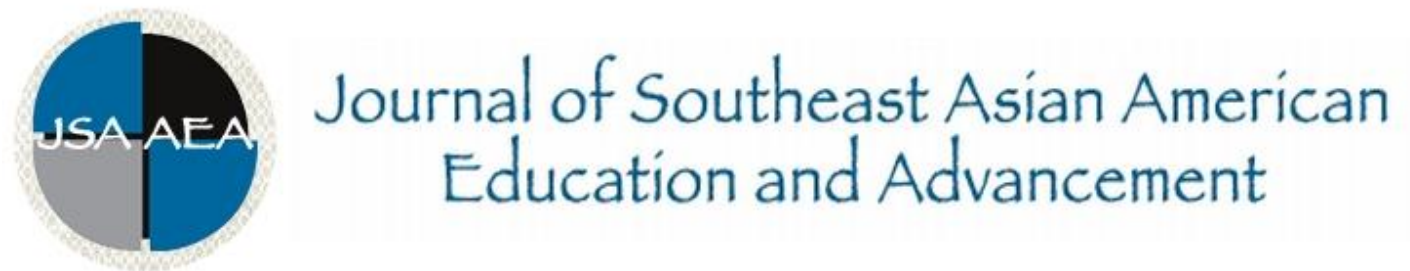

Vol. 12 Iss. 2 Special Issue (2017) www.JSAAEA.org

\title{
The Model Minority Stereotype as a Prescribed Guideline of Empire: Situating the Model Minority Research in the Postcolonial Context
}

\author{
Eun Hee Kim \\ Kansas State University \\ Kay Ann Taylor \\ Kansas State University
}

\begin{abstract}
It has been 50 years since the term, model minority, first appeared in the United States to describe Asian Americans as an ethnic group that overcame the image of the "yellow peril" and successfully climbed the social ladder. Scholars have tried to debunk the myth and reveal racism behind the notion. However, the "overeducation" view has flourished in Asian American Studies as the most popular research direction, serving the socioeconomic self-interest of professors with highly educated Asian Americans as research subjects (Sakamoto, Takei, \& Woo, 2012). To refute the "over-education" view and meet the contextual need to generate a new paradigm of research, this article reviews major themes of the MMS through the lens of postcolonialism based on the discourse of Empire by Hardt and Negri (2000). In the domain of Empire, the model minority stereotype (MMS) is defined as a strategy for imperial control that integrates, differentiates, and manages. Asian American intellectuals and professionals are analyzed from the perspective of Empire with suggestions for future research directions.
\end{abstract}

Keywords: model minority stereotype, Asians, Asian Americans, Empire, postcolonialism, globalization and the Journal of Southeast Asian American Education \& Advancement, it is distributed for non-commercial purposes only, and no alteration or transformation is made in the work. More details of this Creative Commons license are available at http://creativecommons.org/licenses/by-nc-nd/3.0/. All other uses must be approved by the author(s) or JSAAEA. Journal of Southeast Asian American Education \& Advancement, Vol. 12. Iss. 2. Special Issue (2017) ISSN: 2153-8999
} 


\section{Introduction}

It has been 50 years since the term, model minority, first appeared in the United States. William Petersen (1966) described how Japanese Americans could "climb over the highest barriers" of racism and overcome the yellow peril image in his article, "Success Story, Japanese-American Style" published in the New York Times Magazine (p. 43). He identified the reason for success as due to their cultural heritage through respect for authority and strong work ethic, while emphasizing their contrast with African American stereotypes. It was a defining moment that changed the image of Asian Americans from "yellow peril" to "model minority." By the 1980s, similar success stories of Asian Americans were published in major magazines such as Newsweek, Fortune, and Time, which led to the model minority image of Asian Americans becoming rooted in people's minds (Kwon \& Au, 2010).

Hartlep (2013a) wrote that it was not accidental for Asian Americans to be chosen as a model minority, asserting that there was a political purpose behind it. By the mid-1960s, the U.S. government was increasing its intervention in race relations as the Civil Rights Movement progressed with African Americans as the central power (Osajima, 2005). In 1964, President Johnson declared a "war on poverty" to build a "Great Society" (Lyndon Johnson's 'Great Society,' n.d.). The war was intended for social welfare, but it served the status quo by depicting messages: Asian Americans are hardworking with no need for welfare; people of all races can make the same achievement as Asian Americans do through hard work, which proves the United States is not a racist society (Fong, 2008; Osajima, 2005; Sakamoto et al., 2012). This served as a divisive and controlling mechanism for people of color following the Civil Rights Movement when more underrepresented groups joined African Americans in asserting their rights.

For five decades, scholarship on the MMS has attempted to debunk the myth and reveal racism behind the notion. Hartlep (2013a) summarized what MMS research has revealed so far: it has silenced Asian Americans against racism, maintained the status quo, and challenged the mental health of Asian Americans. However, as noted by Sakamoto et al. (2012), the MMS scholarship has centered on racial discrimination that highly educated Asian Americans experience in the labor market. Influenced by the hardworking and over-achieving image of a model minority, the most popular argument in the MMS literature is that Asian Americans are over-educated compared to non-Hispanic Whites and receive lower income for their education, which is known as the "overeducation" view (Sakamoto et al., 2012). This argument is elitist because it pertains to highly educated Asian Americans who are the most privileged group in the labor market (Hartlep, 2013a; Sakamoto et al., 2012). As a result, the view has not only failed to illuminate issues such as class disparities between the highly educated and low educated workers, but suggested more inequality and income gap in the labor market by claiming a higher income for the already highest-earning Asian Americans (Sakamoto et al., 2012). Moreover, the MMS tends to be complied with and embraced by these highly educated and highest-earning Asian Americans as evidenced in several empirical studies as a strategy for success in universities and workplaces (Eguchi \& Starosta, 2012; Ho, 2003; Oyserman \& Sakamoto, 1997; Trytten, Lowe, \& Walden, 2012; Wong, Lai, Nagasawa, \& Lin, 1998).

Related to the tendency that the MMS discourse has mainly served highly educated Asian Americans and the model minority image is positively accepted by them, this article situates the MMS discourse in the postcolonial context, viewing the MMS as a contemporary representation of Orientalism and strategy of the command mechanism of Empire, in the sense that it has accommodated the intellectual class into Empire as its serving agents. According to Said (1978), 
Orientalism has been "successfully accommodated to the new imperialism, where its ruling paradigms do not contest, and even confirm, the continuing imperial design to dominate Asia" (p. 322). In this imperial map, the MMS can be explained as "one of the special triumphs of Orientalism" (Said, 1978, p. 322) because the MMS has been internalized by highly educated Asian Americans, whose minds can be interpreted through what postcolonial scholars have delineated as colonial mentality (Memmi, 1965), inferiority complex (Fanon, 1986), double consciousness (DuBois, 1965), and mimicry (Bhabah, 1984). From the same perspective, borrowing Freire's (1970) term, the MMS can be defined as a prescribed guideline that results in a "prescribed behavior" as a consequence of "having internalized the image of the oppressor and adopted his guidelines" (p. 47).

Through the lens of postcolonialism, this article analyzes major themes of the MMS, Asian American intellectuals as professors and researchers, and highly educated Asian Americans as a workforce in the labor market, specifically in the context of Empire continuously expanding with the process of globalization. This article bases the notion of Empire in the current historical context upon the discourse of Empire by Hardt and Negri (2000). They identified Empire as a "decentered and deterritorializing apparatus of rule that progressively incorporates the entire global realm within its open, expanding frontiers" through effective management of "hybrid identities, flexible hierarchies, and plural exchanges through modulating networks of command" (Hardt \& Negri, 2000, pp. xii-xiii). The imperative of Empire for social control has three moments: (1) inclusiveness of every race, culture, gender, (2) differentiation through the promotion of multiculturalism deprived of political perspectives, and (3) management through hierarchization for its economic expansion (Hardt \& Negri, 2000). The MMS is analyzed through these three facets of imperial control.

\section{The Evolution of Empire and Globalization}

Scholars have differing views on the manifested form of Empire in the current context, specifically whether the United States is the historical representation of Empire inheriting the 20th century European empires (Loomba, 2015). Empires in the colonial period were "expansive, militarized, and multiethnic political organizations that significantly limit[ed] the sovereignty of the peoples and polities they conquer[ed]," specifically with "hegemony, great powers, and international influence" at the borders (Steinmetz, 2014, p. 79). While competition at the borders was the nature of the colonial empires, Empire in the postcolonial context is a "new global form of sovereignty," which is "composed of a series of national or supernational organisms united under a single logic of rule" and the "political subject that effectively regulates global exchanges" (Hardt \& Negri, 2000 , p. xii). It is a "single power that overdetermines them all, structuring them in a unitary way, and treats them under one common notion of right that is decidedly postcolonialist and postimperialist” (Hardt \& Negri, 2000, p. 9).

\section{The Expansion of Empire and Globalization: Past and Present}

The expansion of Empire proceeds with the process of globalization while the historical linkage between empires and globalization provides clues for the current combination between the two (Everill, 2016; Iadicola, 2008; Said, 1978, 1993; Steinmetz, 2014; Wink, 2004). The Bible 
"recorded" the history of empires from Sumer to Babylon, from Babylon to Assyria and Egypt, and then Greece and Rome, which is now a "new empire whose reach is co-extensive with the world itself" (Wink, 2004, p. 25). Idadicola (2008) identified empires as the critical historical forces of globalization, defining them as the "chief globalizers of the world" (p. 5). Everill (2016) found migration, trade, and cultural convergence as the common themes that link globalization and the expansion of the European empires in the 16th century, and the same themes are found in today's globalization process.

While connecting the characteristics of globalization with how empires expanded in the colonial era, scholars have also searched the manifestation of Empire in the present context in the process of globalization. Scholars have identified the United States as a reinstated empire replacing the European empires led by Britain and France (Iadicola, 2008; Kalb, 2006; Pieterse, 2004; Said, 1978, 1993; Smith, 2003, 2005). The United States emerged as the central power of globalization and transnational capitalism in postcolonial scholarship in the early 1990s (Schueller, 2004). Kalb (2006) stated the United States is signifying globalization, with transnational capital through global corporations concentrated in it. Iadicola (2008) defined "the Empire of the United States of America" as the central integrative forces of globalization with its political, economic, cultural, and military control (p. 13). Scholars such as Maira (2009) and Steger (2005) viewed that the imperial power of the United States became stronger with $9 / 11$, which then was used to justify its globalizing force. Steger (2005) said that the involvement of the U.S. military power shifted the soft market globalism in the 1990s to imperial globalism in the 2000s.

Boswell (2004) contended that the United States would remain the strongest in its military power, but its economic hegemony was in decline; therefore, there was no evidence that the U.S. built empire or state was directly controlling other client states. He lamented that the United States was losing its control over its competitor, Europe. However, a series of recent events occurring in Europe today is raising doubts about Europe's hegemony: the influx of migrants and refugees (Migrant crisis, 2016), being the recruitment base and target of attacks of ISIS (Bremmer, 2016), the Euro debt crisis mainly caused by unemployment and the EU's incapability to solve it (Thimann, 2015), and most recently, the United Kingdom's decision to leave the European Union (Brexit build-up to a referendum, 2016).

\section{No Single Dominating Empire}

Another group of scholars view the United States as one of the nation empires emerging through re-regionalization as global power shifts toward a new world order (Okur, 2007). They noted that it is difficult to say a single nation or cluster of nations dominates the world, which was proven by the emergence of the G20 instead of G8 (Buzan \& Lawson, 2014). Brzezinski (2013) included Japan, China, and India as rising powers that disperse the geopolitical map of the world.

With the 20th and early 21st century powers such as the United States and Europe not identified as single dominating empires any longer, it is timely to return to the classic discourse of Empire by Hardt and Negri (2000) to examine where and how Empire is manifested. Hardt and Negri acknowledged the leading role of the United States in establishing a new world order as evidenced by the nation's constitutional project and global expansion. They described Empire as a totalizing process, having its lineage in ancient Rome, where the juridical system and ethical justification were united as an "organic whole" to guarantee peace and justice for all peoples (p. 10). It is a single power "called in being" for the international juridical formation and constitution 
under a global consensus for the purpose of resolving conflicts and expanding the domain of consensuses that maintain the power (Hardt \& Negri, 2000, p. 15). It is in the open space globally constituted, operating on global capitalism, where "power finds the logics of its order always renewed and always re-created in expansion" (p. 190). There is no specific "place" of this sovereign power, and it is "everywhere and nowhere" (p. 190). Hardt and Negri (2000) identified the form of Empire in the supranational role of global bodies, the United Nations and its affiliated organizations: multi- and transnational finance and trade agencies such as the International Monetary Fund and the World Bank and humanitarian organizations like non-governmental organizations (NGOs) that function more symbolically to represent the juridical order of Empire, powered by globalized capitalist production and distribution.

\section{The Society of Control}

Based on Foucault's discourse of power, Hardt and Negri (2000) discussed two essential concepts of Empire - the society of control and biopower. To explain the concepts, they distinguished between disciplinary society and the society of control. Disciplinary society operates upon social commands, reinforcing obedience to its rules and system of inclusion and/or exclusion through disciplinary institutions such as prisons, factories, schools, universities, and so on. Its power sets parameters and limits on thought and practice through sanctions and prescriptions on normalcy and/or deviance.

In contrast, the society of control makes the command mechanisms more "democratic," ingrained in the brains and bodies of the people, so "the behaviors of social integration and exclusion proper to rule are thus increasingly interiorized within the subjects themselves" (Hardt $\&$ Negri, 2000, p. 23). This control is exercised beyond social institutions unlike in the disciplinary society, through "flexible and fluctuating networks" (p. 23). The society of control works with the biopolitical nature of power, a form of power that "regulates social life from its interior, following it, interpreting it, absorbing it, and rearticulating it" (pp. 23-24). The power becomes most effective over people's lives when every person "embraces and reactivates" its integral, vital function "of his or her own accord" (p. 24). It reaches the deepest consciousness and bodies of people so the society can function as a single body (Hardt \& Negri, 2000).

Hardt and Negri (2000) took NGOs as examples completely immersed in the biopolitical context of the constitution of Empire. It is because these NGOs demonstrate the imperial order as a peaceful biopolitical context, providing moral and ethical justification of the imperial control. In this society, people's individuality, when contrasted with its order, is determined by the ethical, political, and juridical categories of Empire, but the whole process is done peacefully (Hardt \& Negri, 2000). It means the imperial control is so immersed into people and their everyday lives that they do not realize they are under its imperial control.

\section{Imperatives of Empire: Three Controlling Mechanisms}

Hardt and Negri (2000) delineated the controlling mechanism of Empire, which consists of three imperatives: (1) inclusive, (2) differential, and (3) managerial. The first imperative, inclusiveness, represents the liberal aspect of Empire. It sets aside differences, which means it actually removes "the potential of the various constituent subjectivities" resulting in Empire's appearance as a 
peaceful domain for universal integration, sending a message that all can live harmoniously within the domain without resistance or conflict (p. 198).

Second, its differential moment celebrates and actively promotes ethnic identities and cultural differences with the support of global bodies. These differences are non-political in nature, not causing uncontrollable conflicts, to function as a "force of peaceful identification" (p. 199). Official promotions of multiculturalism in the United States are examples. Empire's strategy to be differential does not mean it creates differences but makes what already exists work (Hardt \& Negri, 2000).

Finally, the differential moment is followed by the managerial or hierarchical moment, which represents Empire's economic command. Unlike colonial power that thrives on identity separation, Empire prospers with movement and mixture, operating modulation and transformation to cope with the multiplicity and complexity of variables and come up with various solutions, which are "always incomplete" but still effective and pragmatic (Hardt \& Negri, 2000, p. 199).

Hardt and Negri (2000) provided examples that show the managerial moment of the imperial society of control most efficiently. New England factories and Appalachian coal mines in the early 20th century relied on European immigrants, who brought their traditions and cultures to the new land. Bosses carefully managed these immigrant workers by their national backgrounds in each workshop to produce a strong mechanism of command in each mine. Another example is a banana plantation in Central America, where labor was managed by differentiating ethnic groups subjected to varied methods and degrees of exploitation and repression. As a result, hostility and divisions among ethnicities occurred, which ultimately improved production with well facilitated control (Bourgois, 1989, as cited in Hardt \& Negri, 2000).

These examples demonstrate a primary strategy of the imperial society of control is not cultural assimilation, but multiculturalism, or peaceful co-existence of multiple cultures. This was an emerging phenomenon in the late 20th century when ethnic and national diversities rose in Europe, Africa, Asia, and the Americas (Hardt \& Negri, 2000). It was time to witness Empire's real power thrived on "contingency, mobility, and flexibility" with its solution to conflict affirming and managing these differences effectively for its command mechanism (Hardt \& Negri, 2000, p. 200).

\section{The Model Minority Stereotype and Images of Asian Americans}

To understand and interpret the MMS in the postcolonial context, it is necessary to review major themes developed by the MMS scholarship and analyze them based on the characteristics of Empire explained above. The first two subjects - the MMS and images of Asian Americans and the MMS and racism are the most studied subjects in the MMS discourse, which are comprehensively derived from the first annotated compilation of resources on the MMS (Hartlep, 2013b). The last subject is Asian American intellectuals and professionals and their embrace of the MMS. Though rarely studied, this subject will suggest a stepping stone that bridges what has been studied so far with what can be researched further in relation to postcolonialism and the notion of Empire.

Scholarship on the MMS and images of Asian Americans are grounded in Said's (1978) scholarship. Orientalism refers to a "system of representations framed by a whole set of forces that brought the Orient into Western learning, Western consciousness, and later, Western empire" (Said, 
1978, pp. 202-203). McLeod (2010) summarized six important points of Orientalism described by Said $(1978,1985)$ as follows:

(1) Orientalism sets up a binary division between the Orient and the Occident, resulting from the West's dreams, fantasies, and assumptions about the East.

(2) Orientalism is the West's dreams, fantasies, and assumptions about the East as a radically different, contrasting place.

(3) Orientalism is institutional because such assumptions have circulated academies and institutions as legitimate knowledge and truths, and as subjects for study.

(4) Orientalism is literary and creative because it overlaps with the multitude of creative arts, producing new forms of representation and genres of writing.

(5) Orientalism is legitimating and reproductive because it perpetuates itself, functioning as a system of representations for imperial control.

(6) "Latent" and "manifest" Orientalism are distinguished. Latent Orientalism represents the unchanging, constant assumptions about the Orient over time, which is specified in manifest Orientalism at different historical times.

With these concepts of Orientalism in mind, many studies have been conducted on how Asian Americans are portrayed by media (Hamamoto, 1994; Osajima, 2005; Paek \& Shah, 2003; Shim, 1998; Taylor, Landreth, \& Bang, 2005; Taylor \& Stern, 1997; Zhang, 2010). Of this work, Osajima (2005) comparatively analyzed the way the U.S. press portrayed Asian Americans in the 1960s and in the 1980s, specifically how the image of Asian Americans has been shaped as a model minority in the social and political context. His findings indicated that compared to the 1960s, the MMS discourse in the 1980s became diverse to reflect more complex images of Asian Americans, even criticizing Asian Americans' success image and addressing their advancement into the political arena. He pointed out that the discourse in the 1980s was characterized by more criticism and balanced views of Asian Americans. It became less political using non-racial terms than in the 1960s when more racial perspectives were used to compare Asian Americans with other minorities. Hard work remained as the reason for success of Asian Americans in both periods (Osajima, 2005).

Studies have found that the MMS is a divide-and-conquer strategy because it presents Asian Americans as a success model to follow and justifies no need of affirmative action and social welfare for minorities (Cheng, 1997; Chou, 2008; Kia, 2007). Interestingly, the changes of the MMS discourse in Osajima's (2005) study indicated that the MMS is not solely a divide-andconquer strategy any more, unlike in the 1960s when it was devised and mainly compared Asian Americans with other minorities. Based on what is delineated by Hardt and Negri (2000), the MMS can be understood as an imperial strategy that integrates, differentiates, and manages.

\section{Model Minority Stereotype: Serving the Interests of Empire}

How does the MMS integrate, differentiate, and manage, in other words, welcome all within its boundaries, take away any possibility that leads to "real" political resistance and conflicts, and make all minorities, including Asian Americans, serve the interests of Empire? By accepting criticism and even promoting more criticism as evidence of its flexibility and acknowledgement

of differences. The criticism should not possess any capability or intention to organize an opinion 
that can lead to mass movement, staying safely within the territory where it is supposed to be, which is the realm of "discourse" with other topics whether in media or academia. This is why Asian Americans' advancement in politics in the discourse of the 1980s should not be understood as if they are making "real" political advancement, because it is not the only topic, but one of the diverse topics of Asian Americans that are allowed to be discussed before Empire's all-welcoming gaze. Again, Empire acknowledges multiplicity and diversity, but does not want criticism to develop into political resistance and conflicts. Osajima's (2005) finding that the tendency of the discourse of the 1980s became less political using non-racial terms is additional evidence the MMS discourse has settled down for "peace" or has been led to that direction. In this way, the purpose Empire has placed on the MMS has been successfully accomplished, giving false thought to Asian American intellectuals and activists that their rights are being achieved or improvements are on the way, particularly as related to their economic conditions and welfare.

In addition, the MMS shows the managerial moment of Empire for its economic expansion as exemplified by Hardt and Negri (2000) in how the labor of the plantation and mine workers was managed. The MMS, as a divide-and-conquer strategy, is specifically applied for this managerial moment of Empire as Chae (2008) stated that the MMS is a strategy devised and used by capitalists. Hard work as a signifier of success of Asian Americans in both the 1960s and the 1980s indicates that the MMS is used for the managerial or hierarchical moment of imperial control. It was a method devised for Asian Americans out of the varied methods used for different ethnicities and cultures. As the economic face of Empire, this strategy makes people competitively serve the economic interest of the imperial society like the plantation workers on the banana plantation in Central America. In this sense, the MMS carries a strong degree of exploitation among the varied methods because it requires arduous work that spans generations, which incessantly tells them to aim for higher education and higher paying jobs. The tendency to work hard and be obedient to authority is culturally embedded in Asian Americans' nature; however, it is not in fact and this will be explained later. The MMS is a successful example of an imperial strategy ethnically and culturally improved and reinforced in the process of the strategical development for more effective control. Because the MMS sends out the message hard work equals success not only to the ethnic group it was intended for, but to other minorities as well, then all yearn for the same success through hard work competing with Asian Americans. The MMS, therefore, carries the triple imperative of Empire: inclusion, differentiation, and management. Its divide-and-conquer facet is specially designed for the economic order of Empire.

\section{The Changing Form of the Model Minority Stereotype}

In previous research, the MMS has been studied as a divide-and-conquer strategy as if it is an innate attribute. To introduce Osajima's (2005) article in his edited book, Ono (2005) wrote, "while it appears to be a compliment, in fact it implies that Asian Americans can never be on equal footing with Whites, even as it simultaneously creates a 'divide and conquer' strategy to win over Asian Americans and pit Asian Americans against Blacks and Latinas/os" (p. 8). As indicated in this quote, the MMS was devised to present Asian Americans as a triumphant case against other minorities. It also shows that Asian Americans were intentionally selected as a model minority by the U.S. government to shift away negative international attention from itself (Hartlep, 2013a). However, these identified purposes, for which Empire created the MMS, require scrutiny through the changing form of the stereotype. 
The pattern of the imperial control changes continuously regardless of regions and cultures, but continuously modifies itself fitting diverse regions and cultures (Hardt \& Negri, 2000). It suggests imperial strategies can always change according to the contextual needs, and the MMS is one of the "variety of always incomplete but nonetheless effective solutions" (Hardt \& Negri, 2000, p. 199). Therefore, the MMS should not be understood as a notion with fixed attributes because the imperial society of control works on "circuits of movement and mixture" creating multiple strategies (Hardt \& Negri, 2000, p. 199). We can see how the notion of model minority emerged and how long it has lasted. Its precedent historical form was the "yellow peril" that lasted from the late 19th century untill 1966 when the MMS appeared. It has lasted 50 years. Its longevity indicates that the model minority, like the "yellow peril," is a contextual representation, or manifest Orientalism of latent Orientalism, which can take a different shape at any time according to Empire's hierarchical need and interest. Therefore, caution must be exercised when assigning a definition that characterizes the MMS concretely as seen in its current form. It has the potential to fixate inquisitive minds on given features and attributes of the notion, blinding them from identifying what form or shape it will take in the future and how the transformation will occur. This is the reason, as Hartlep (2013b) noted, the MMS discourse should not revisit what has been already researched, but instead generate new paradigms. Through the new paradigms, the MMS can be further studied and analyzed in the new historical context on a continuum of the past.

The new historical context requires MMS research expand its scope beyond the United States where it originated because Empire does not limit its expansion within regions and its strategies work globally. Hartlep (2014) also highlighted the need to turn to the globe, by saying that the MMS is not limited to Asian Americans in the United States, but applied to Asians in Asian countries. It can be seen in the transnational network of highly skilled and educated Asian workers and their efforts to conform to the norm imposed on them. For example, Kaibara (2014) found Japanese elites in Japan and the United States collaborated to improve the image of Japanese immigrants in the United States by organizing reform campaigns to present Japanese immigrants as a good model conforming to the social and cultural norms in the United States. These activities serve Empire's interest well. The MMS that was originally devised for Asian Americans now functions globally through voluntary efforts, not only of the targeted, but of the networked around them, maximizing its interest across nations. This transnational trend can signify a changing pattern of imperial control and its strategy, powered by globalization and its capitalist system.

Again, it merits mentioning that the MMS as an imperial strategy is not bound to a specific region or an ethnic group. It is evidenced in research that shows many other ethnic groups such as Germans, Jews, Senegalese, Black Mormons, Black Methodists, and Mormons in general have been labeled as model minorities (Hartlep, 2013b). Research also shows that the term, model minority" appeared ten years earlier in China to describe the schooling experience of Koreans in China before it was used in the United States in the 1960s (Fang, 2010, as cited in Hartlep, 2013b). From this perspective, identifying how it will be manifested through the global capitalist network will be another task for future MMS research.

\section{The Model Minority Stereotype and Racism}

Another important line of scholarship that has developed regarding the MMS is that it has concealed racism by presenting Asian Americans as a model minority group that has overcome racial barriers and shown that the United States is not a racist society, but rather a land of 
opportunity (Chou, 2008; Chou \& Feagin, 2008; Maddux, Galinsky, Cuddy, \& Polifroni, 2008; Saito, 1997; Wing, 2007). The major argument is that Asian American success implies that other minorities fail, which results in privileging Whites and maintaining the status quo (Hartlep, 2013b).

To understand this argument in the postcolonial context, we first refer to Hardt and Negri (2000) regarding the shifting configurations from modern racism to imperial racism. They said it looks like racism has declined due to the changed form and strategies, but it takes a different form and strategies under the imperial control. What makes it difficult to identify the form is that what imperial racism says is not really different from what modern anti-racism says: biological differences cannot divide human races, and individual behaviors, abilities, or aptitudes are not based on blood or genes, but on "different historically determined cultures:" therefore, differences are "not fixed and immutable but contingent effects of social history" (p. 192). It does not appear to be racism, giving the message that cultures change, mix, and form hybrids. However, imperial racism sets limits to this notion because it is useless and even dangerous to let cultures mix for imperial control (Hardt \& Negri, 2000). Cultures still function as the ground for separation, only replacing biology in modern racism, but it appears fair with this rationale, "all cultural identities are equal in principle" (p. 192). However, this principle still separates races because it works only when people "act" their races (p. 192). What Hardt and Negri noted is that imperial racism segregates, but does not impose racial hierarchy, i.e., superiority or inferiority among races or ethnicities. Citing Deleuze and Guattari (1987), Hardt and Negri challenge the notion that traditional binary divisions and exclusion are still being adopted as the essence of racial practice to explain today's racism. They said imperial racism does not exclude anyone, with no designation of Other. Therefore, White supremacy is not related to the fear or hatred of strangers as traditionally believed, but is a result of a hatred of differences and subordinating the differences caused by the degrees of differences in proximity of the neighbor, which is associated with "differential inclusion" of imperial control (Hardt \& Negri, 2000, p. 194).

\section{Racism and Ethnicization}

Hardt and Negri (2000) used "differential racism" because this type of racism "integrates others with its order and then orchestrates those differences in a system of control" (p. 195). It is not bound to a "place" that designates Other, but appears to operate with no fixed boundaries in a way that "destabilizes any notion of place" (p. 195). Imperial racism is concerned with how to manage differences within its domain expanding continuously (Hardt \& Negri, 2000).

Hardt and Negri's (2000) argument is better understood through the discourse of racism by Balibar and Wallerstein (1991), who said the capitalist world economy is behind the practice of racism. Balibar and Wallerstein (1991) noted fear of someone or another group is secondary to what defines the practice of racism. In other words, ejecting the Other can deal with conflicts in a way to secure an environment free from the need to deal with differences, but it means at the same time a loss of labor, resulting in a loss for a system built upon continuous production, realization, and accumulation of capital (Balibar \& Wallerstein, 1991). Here is the need to integrate the Other into the work force, and when it happens, racism takes the form of "ethnicization" or an "occupational-reward hierarchy" whose details can vary depending on the needs of the economy at a particular time and place (Balibar \& Wallerstein, 1991, pp. 32-33). In other words, groups can move up or down, disappear, combine with others, break apart, or be newly created in the ranking system based on the hierarchical needs of the economic context (Balibar \& Wallerstein, 1991). As 
an example, a study conducted on immigrant construction workers in Modena identified that employers used ethnic stereotypes against immigrant workers such as "Central African immigrants work harder and more obedient and amenable than Tunisian workers" (Daly, 2002, p. 167). However, these stereotypes are subject to change contingent on the managerial needs of the system.

This ethnicization or occupational-reward hierarchy is contextually exemplified in the notion of the MMS. Asian Americans were "yellow perils" in the ranking system with their occupation as railroad workers in the early 19th century. Now they have moved up to a "model minority," a major promotion in the hierarchy with hard work, higher education, and high-paying jobs subsequently. Asian Americans' success as a model minority has been attributed to hard work and other similar cultural traits that are believed to be inherited and brought by them. However, what must be remembered is that the notion of the MMS focuses on how Asian Americans are culturally different, not racially different from other minorities. Chou (2008) said American capitalism is behind the MMS, which determines race relations in the United States by the degrees of performance of different races. When Chou's argument is extended to the context of Empire, the capitalist world economy is behind it, continuously powering the capitalist Empire, where American capitalism is a major part of it, considering the MMS in today's global network is not limited only to Asian Americans.

\section{Maintaining the Status Quo}

The status quo argument is reviewed in the imperial context. Chou (2008) stated that the MMS is an example that shows cultural differences are essentialized, replacing the notion of races and used to stabilize the White supremacist ideology. Thus, the MMS ethnicizes and stereotypes Asian Americans by their cultural differences from other minorities, and it has been used to maintain the status quo of the White-dominant society.

To analyze status quo of this nature as realized in the MMS research, it helps to review how Balibar and Wallerstein (1991) defined "culture" in the postcolonial context as it relates to the ethnicization of the occupational hierarchy. Considering all labor is exploited in the capitalist economy based on the surplus-value system, there are some laborers who lose more surplus-value than others, which creates household structures where more highly paid workers are located higher in the structures and less highly paid workers in the lower structures. In this occupational hierarchy, different work forces need different kinds of guidelines for normal behavior, which is "not in fact genetically determined," but "taught" so that they can be "socialized into reasonably specific sets of attitudes" (p. 83). This is the "culture" of an ethnic group, which "precisely" describes "the set of rules" passed down from one generation to another and taught in homes and schools (p. 83). However, due to the unequal nature of the capitalist economy, the economic processes need to be restructured constantly, and this requires the behavior of work forces to change too (Balibar \& Wallerstein, 1991). This landscape suggests that the culture of an ethnic group can change because a different set of rules is given depending on where they are located in the ranking system for historical needs of capitalism.

In this sense, the status quo that has been discussed in the MMS research needs to be understood not just as a state, for which the MMS is used to consolidate White supremacy and race relations. Rather, it is a state where the MMS as a manifested historical imperial strategy serves changing hierarchal dynamics, through which continuous imperial expansion is achieved. The

MMS works with culture and culture replaces the notion of race, as Chou (2008) said. But as an 
imperial strategy and set of behavioral rules prescribed for Asian Americans, the MMS will not stay essential forever, always involving the potential to change as needed for the existence and expansion of Empire. These command mechanisms in the imperial society, as a reminder, work through people's brains and bodies so thoroughly that they are supposed to behave autonomously and voluntarily as culturally prescribed without realizing it.

Sakamoto et al. (2012) mention, however, the MMS will persist because the MMS "promotes the socioeconomic self-interests of the professors who currently control the Asian American Studies establishment that in turn provides political legitimacy for the universities that employ them" (Sakamoto et al., 2012, p. 309). As long as the MMS serves academics as the source of professions, it will not cease to exist. Rather, it will continue to serve the legitimacy of the universities where knowledge is produced and distributed through people's bodies and minds for more efficient imperial control. In this way, the MMS has veiled Asian American intellectuals' eyes not to see what exists beyond what is visible, making them constantly revisit existing topics and produce the same results as per Hartlep (2013b). Nor can the authors of this article be excused from this criticism. They might seek to draw on the notion for their academic life expansion and extension. How should these intellectuals, including professors who feed on the MMS, be viewed in the realm of Empire? This is another area this self-critical contribution explores.

\section{The Model Minority Stereotype and Intellectuals}

Colonized intellectuals and their psychology have been addressed by well-known authors of postcolonialism such as Fanon (1986), Said (1978), Bhabha (1984, 1994), and Freire (1970). Their analyses are highly relevant to intellectuals and professionals in the discourse of the MMS, whether they are the subjects or the objects of the MMS research. They resemble colonized intellectuals described by the authors. Two groups are addressed here: (1) intellectuals in academia, including graduate students, professors, and researchers who study the notion of the MMS on the basis of the "over-education" view and (2) Asian American students in higher education and highly educated professionals who have been studied as the objects of the MMS research, specifically from the viewpoint of how the MMS is embraced and conformed to by this group. The second group will be reviewed through empirical research though studies have been rarely conducted.

Said (1978) focused on the power relationship between the Orient and the Occident, using "imperial agents" (Arendt, 1973, as cited in Said, 1978, p. 240) to describe the role of intellectuals as the servants of Orientalism. Intellectuals' task is to move Orientals into action to actively serve the empire (Said, 1978). Though Said (1978) used "imperial agents" in reference to White Oriental experts who brought the Orient under the control of the empire through "the collective academic endeavor" (p. 240), the term can be applied to Asian American intellectuals as the same theme is identified in them as follows:

What is required of the Oriental expert is no longer simply "understanding": now the Orient must be made to perform, its power must be enlisted on the side of "our" values, civilization, interests, goals. Knowledge of the Orient is directly translated into activity, and the results give rise to new currents of thought and action in the Orient. (p. 238)

Today, this task seems to be done through intellectuals in universities. Sakamoto et al. (2012) argued that the "over-education" view has been the central theme of the MMS research, 
whose influence is becoming the "conventional wisdom" in Asian American Studies (p. 311). They stated the reason it will persist is that it "promotes the political power of universities in the current era of increasing inequality and the rising exploitation of the working class that are fostered by educational credentialism" (p. 309). This quotation, in connection with Said's (1978) remark above, implies that the MMS as academic discourse has securely found its home in a scholarly circle, growing with more intellectuals joining the power of scholarship whose basis is built upon Empire as a device of institutional control. As the MMS settled in academic discourse, these same intellectuals have, in fact, supported class disparities in the labor market by basing their research on the "over-education" view that has served highly educated Asian Americans (Sakamoto et al., 2012).

The role of intellectuals as the agents of Empire is related to the role of the universities in the society of control, where the command mechanisms become "ever more 'democratic,' ever more immanent to the social field, distributed throughout the brains and bodies of the citizens" (Hardt \& Negri, 2000, p. 23). Consider how knowledge is circulated "democratically" and "capitalistically" in today's universities. Universities constantly produce critical ideas, accept criticism against the critical ideas, and provide venues where all possible lines of scholarship are formed and developed through the process. Being critical is not optional, but essential for academic survival, and knowledge produced in this way creates scholarship and expands the scholarship with increasing disciplinary subsets. In this sense, knowledge is produced and grows through criticism democratically, although circulated for expansion capitalistically in its nature. Universities, therefore, are the place where the two essential principles of Empire-democracy and capitalism - effectively combine to maximize the influence as institutions of the imperial command mechanism, for the knowledge produced and circulated to be ingrained in people's minds and bodies or thought and actions officially through their credentials.

Freire's (1970) term, "prescribed behavior," meaning the behavior of the oppressed following the guidelines of the oppressors, explains how the knowledge produced this way is distributed throughout the brains and bodies of people psychologically. "Prescription" in Freire's term is defined as "the imposition of one individual's choice upon another, transforming the consciousness of the person prescribed to into one that conforms with the prescriber's consciousness" (p. 47). In the postcolonial context, a prescribed behavior is a behavior that occurs as a result of embracing and conforming to Empire's strategies imposed on the oppressed. When this notion is applied to the MMS, intellectuals can be viewed as agencies with Empire's strategy inverted into themselves as a prescribed guideline, working to transform the consciousness of Asian Americans into the most appropriate form to serve the system through their bodies. This picture shows that the brains of intellectuals activate or deactivate the bodies of people, i.e., Asian Americans.

Fanon's (1963) analysis of colonized intellectuals reveals insight into the minds of Asian American intellectuals. In concert with Osajima's (2005) findings, the MMS discourse has changed from comparing Asian Americans with other minorities in the 1960s to Whites in the 1980s. Further, the "over-education" view compares the income level of Asian Americans with that of Whites (Sakamoto et al., 2012). These discourse changes indicate Asian Americans' promotion in the occupation-reward hierarchy has signified thinking in terms of Asian Americans' superiority to other minorities, resulting in comparisons with Whites in education and income via the developing notion of MMS. Simultaneously, however, the same discourse change might represent Asian Americans' inner struggle about the reality that never allows them to be on equal ground with Whites. The psychological mind they experience in this situation can be referred to 
as "inferior complex" (Fanon, 1963, p. 18). Westermann (1934) said this inferior complex is "particularly strengthened among the most educated" with restless struggle and assimilation efforts to be like colonizers (as cited in Fanon, 1986, p. 25). This psychological aspect of intellectual Orientals, regarding the tendency to conform and adjust to the Western view of the Orient, is termed inverted Orientalism (Eisenstadt \& Schluchter, 1998; James, 2012).

"Mimicry," as termed by Bhabha (1984, 1994), describes Asian Americans' psychology in a similar context. It is defined as an imitating act and thought of the colonized to resemble the colonizer. He further described mimicry as follows:

Mimicry represents an ironic compromise ... the desire for a reformed, recognizable Other, as a subject of difference that is almost the same, but not quite . . . the sign of a double articulation; a complex strategy of reform, regulation, and discipline, which "appropriates" the Other as it visualizes power ... the sign of the inappropriate, however, a difference or recalcitrance which coheres the dominant strategic function of colonial power . . one of the most elusive and effective colonial power and knowledge. (Bhabha, 1984, p. 126, italics in original)

Mimicry is ambivalent in nature, characterizing the colonial subject as partial, incomplete, and virtual, which is made through "strategic limitation or prohibition within the authoritative discourse" (Bhabha, 1984, p. 127). As such, the "over-education" argument as a research direction does not address the MMS as a controlling strategy in the command mechanism of the regime; rather, it appropriates Asian Americans for the imperial power that limits the argument within the domain of discourse strategically in an effort to make the group recognizable not just as a model minority, but a more presentable model minority, i.e., well-educated and disciplined.

\section{A New Model Minority Stereotype Research Paradigm}

What could be an alternative direction of research to the "over-education" view? A few empirical studies have sought to examine how the MMS is embraced by highly educated Asian Americans. These studies have significant importance because they offer a new perspective and approach to highly educated Asian Americans. In this research direction, highly educated Asian Americans are viewed not as victims of the system, but as a privileged group in the immigrant labor market compared to their less educated and skilled peers.

Oyserman and Sakamoto (1997) studied Asian American undergraduate students and found that the model minority image is accepted positively by some of them. In another study, Wong, Lai, Nagasawa, and Lin (1998) categorized the cultural values the model minority image gives to Asian Americans as middle class characteristics such as strong work ethic, high achievement motivation, patience, discipline, respect for authority, and conformity. Their findings show that Asian American undergraduate students perceived themselves as more prepared, motivated, and more likely to be successful in their careers than Whites (Wong et al., 1998). Another study reported the impact of the facets of the MMS on Asian American students' lived experiences (Trytten, Lowe, \& Walden, 2012). In the same study, many of the participants believed that the United States is a racially equal society with color-blind meritocracy in general though they said the MMS is not true for Asian Americans (Trytten et al., 2012). 
In addition, the MMS has been found to be embraced as a workplace strategy by young Asian American professionals (Eguchi \& Starosta, 2012; Ho, 2003). In a study on college-educated Asian American professionals, the participants felt that they embrace and perform the model minority image to survive in their workplace and move up the social ladder (Eguchi \& Starosta, 2012). Ho (2003) examined how young Asian American professionals act upon the model minority image. Ho's (2003) findings indicated the participants' efforts to act upon the image and achievements in the workplace instead marginalize them racially because they will never achieve "Whiteness" (p. 150). However, the participants were not aware they were reinforcing their image as a model minority through their performance and thereby furthering their marginalization (Ho, 2003). Ho (2003) found that their class privilege caused them to ignore or deny racial politics in their workplace. He asserted that these highly educated Asian American professionals are a privileged group with better access to education and employment compared to less educated Asian Americans (Ho, 2003).

Studies to date demonstrate that class disparities among immigrant Asians are best shown in education because it is "one of the few avenues they have to gain status in the new country and climb the socioeconomic ladder" (Zakeri, 2015, p. 245). This explains the reason why high academic attainment has been a core theme that shapes the MMS (Kim \& Aquino, 2015). High academic achievement of Asian Americans has consequently allowed them to take the "ambiguous middle position" that "maintains systems of privilege and power" (Velasquez, 2015, p. 98). Therefore, highly educated Asian Americans are the group that best represents the core theme of the MMS, "success through hard work."

Fanon's (1963) analysis of the privileged working class applies to highly educated Asian Americans. He stated this privileged working class is "the fraction of the colonized who are indispensable for running the colonial machine," constituting "the most loyal clientele of the nationalist parties" of his time and occupying the bourgeois circle of the colonized people through their privileged position (Fanon, 1963, p. 64). More studies viewing highly educated Asian Americans as a privileged group highly ranked in the occupation-reward hierarchy will reveal the invisible reality under the shadow of power. They are serving the maintenance and expansion of Empire.

\section{Conclusion}

The MMS targets Asian Americans. Due to the ethnicity involved, it has been primarily studied by Asian or Asian American professors and researchers who seek academic careers and development. One of the authors of this article is an Asian researcher who is pursuing the same. Great scholarly contributions have been made to debunk the model minority myth for the last 50 years. Scholars have analyzed Asian Americans' image depicted by media and found that the MMS is a contextual representation of the West's latent view of Asia and Asians, with its roots in Orientalism. In addition, they have learned that the MMS has shielded racism and perpetuated Asian Americans as foreigners. However, as Sakamoto et al. (2012) pointed out, scholarly attempts to debunk the myth and reveal racism behind it has caused the "over-education" argument to flourish in Asian American Studies, serving the most privileged group of Asian Americans while implicitly ignoring the class disparities in the labor market.

In response to Sakamoto et al.'s (2012) challenge and to meet the current contextual needs that require a new research paradigm, this article has addressed major themes of the MMS through 
the lens of postcolonialism based on the discourse of Empire by Hardt and Negri (2000). Particularly, this article sought to identify the problems of the "over-education" argument through the psychology of colonized intellectuals by defining the role of Asian American intellectuals as imperial agents who serve Empire, which is done through their knowledge production and distribution within the domain of academic discourse in the legitimate power of universities in the society of control. Empirical studies on Asian American college students and professionals who embrace and conform to the model minority image have been reviewed, defining them as a privileged group in the occupation-reward hierarchy of Empire.

In postcolonialism, the MMS is not an ideological device, but a pragmatic apparatus of the command mechanism of Empire. For its pragmatic purpose, the MMS in its current form is always subject to change as long as the power of Empire can be maintained and expanded. See how pragmatic it is-the most erudite people have been captured by the "over-education" view.

The pitfall is that the "over-education" view reinforces the occupation-reward hierarchy because it positions highly educated Asian Americans within the mechanism of ethnicization, claiming more socioeconomic promotion in the reward hierarchy. Rather than debunk the model minority myth, it serves the notion of the MMS by presenting Asian Americans as a model with good cultural values leading to high academic attainment, which should be better rewarded and more highly positioned in the hierarchy through higher compensation. As long as this view persists as a primary argument in the MMS research, Asian Americans will continue to be charged as complainers who want more as seen in a recently published Economist (2015) article: "The model minority is losing patience: Asian-Americans are the United States' most successful minority, but they are complaining even more vigorously about discrimination, especially in academia" (para. $1)$.

For the past five decades, scholarship has found how the MMS has been used to maintain the status quo, victimizing and marginalizing the group and stirring conflicts among minorities. Now is the time to turn to how the MMS as a prescribed guideline of an imperial strategy of Empire has blinded people from the presence of Empire and its expansion process through the capitalist world economy, which is not limited to Asian Americans in the United States, but Asians all over the world. The most pernicious part of this imperial society of control is that its power operates through the consciousness and bodies of people and makes them voluntarily function as servants who do not realize their role as active performing agents of Empire. No Asian American intellectuals, students, or professional workers are free from this charge as long as the MMS and any future transformation of the MMS ethnicizes Asian Americans.

This article commenced from a self-reflective and self-critical view of Asian American Studies researchers in academia. With more researchers expected to enter Asian American Studies, this contribution strives to provide a chance for them to see themselves in the same self-reflective and self-critical way in order to advance the MMS discourse into the terrain of Empire and confront its "homogenizing and heterogenizing flows" powered by the global capitalist economy (Hardt \& Negri, 2000, p. 46). In the realm of Empire, more empirical studies on the MMS are suggested in the following directions: (a) how the notion of MMS takes a new shape in the process of globalization as manifest Orientalism - transnational networks of Asians and Asian Americans studied by Kaibara (2014) as an example, (b) how the entry of highly skilled and educated Asian Americans and Asian immigrants into the labor market deepens social and economic disparities between them and their counterparts, (c) how the MMS is embraced by Asians in Asian countries and in other continents in the form of inverted Orientalism, and (d) how the MMS is represented in the psychology of highly educated and skilled Asian and Asian American intellectuals including 
professors and researchers from the postcolonial perspective. We hope more self-reflective and self-critical professors and researchers will contribute to these suggested directions to enrich future MMS research in Asian and Asian American Studies. Such research will be the venue to reveal the shadowy substance of Empire as the power of air with no concrete form, which continues its expansion through globalization.

\section{References}

Arendt, H. (1973). The origins of totalitarianism. San Diego: A Harvest Book.

Balibar, E., \& Wallerstein, I. M. (1991). Race, nation, class: Ambiguous identities. New York: Verso.

Bhabha, H. K. (1984). Of mimicry and man: The ambivalence of colonial discourse. October, 28, $125-133$.

Boswell, T. (2004). American world empire or declining hegemony. Journal of World-Systems Research, 10(2), 516-524.

Bourgois, P. (1989). Ethnicity at work: Divided labor on a Central American banana plantation. Baltimore: Johns Hopkins University Press.

Bremmer, I. (2016, March 22). These 5 facts explain why Europe is ground zero for terrorism. Time. Retrieved from http://time.com/4268579/brussels-attacks-islamist-terrorism-isis/

Brexit build-up to a referendum: EU referendum results. (2016). Retrieved from http://www.economist.com/Brexit

Brzezinski, Z. (2013). Strategic vision: America and the crisis of global power. New York: Basic Books.

Buzan, B., \& Lawson, G. (2014). Capitalism and the emergent world order. International Affairs, 90(1), 71-91.

Chae, Y. (2008). Cultural economies of model minorities creation. In Y. Chae, Politicizing Asian American literature: Towards a critical multiculturalism (pp. 19-30). New York: Routledge.

Cheng, C. (1997). Are Asian American employees a model minority or just a minority?. The Journal of Applied Behavioral Science, 33(3), 277-290.

Chou, C. C. (2008). Critique on the notion of model minority: An alternative racism to Asian American? Asian Ethnicity, 9(3), 219-229.

Chou, R. S., \& Feagin, J. R. (2008). The myth of the model minority: Asian Americans facing racism. Boulder, CO: Paradigm Publishers.

Daly, F. (2002). Migrant workers in the construction industry: The experience of Tunisians in Modena. In S. Fenton \& H. Bradley (Eds.), Ethnicity and economy: 'Race and class' revisited (pp. 160-182). New York: Palgrave Macmillan.

Deleuze, G., \& Guattari, F. (1987). A thousand plateaus. (B. Massumi, Trans.). Minneapolis: University of Minnesota Press.

DuBois, W. E. B. (1965). The souls of Black folk. In J. H. Franklin (Ed.), Three Negro Classics (pp. 207-389). New York: Avon Books.

Eguchi, S., \& Starosta, W. (2012). Negotiating the model minority image: Performative aspects of college-educated Asian American professional men. Qualitative Research Reports in Communication, 13(1), 88-97. 
Eisenstadt, S. N., \& Schluchter, W. (1998). Introduction: Paths to early modernities-A comparative view. Daedalus, 127(3), 1-18.

Everill, B. (2016). Globalization and empire. London, UK: John Wiley \& Sons.

Fanon, F. (1963). The wretched of the earth. New York: Grove Press.

Fanon, F. (1986). Black skin, white masks. London, UK: Pluto Press.

Fong, T. P. (2008). The contemporary Asian American experience: Beyond the model minority. New York: Pearson.

Freire, P. (1970). Pedagogy of the oppressed. New York, NY: Continuum.

Hardt, M., \& Negri, A. (2000). Empire. Cambridge, MA: Harvard University Press.

Hartlep, N. D. (2013a). The model minority myth: What 50 years of research does and does not tell us. Diverse: Issues in Higher Education. Retrieved from

http://diverseeducation.com/article/52979/

Hartlep, N. D. (2013b). The model minority stereotype: Demystifying Asian American success. Charlotte, NC: Information Age Publishing.

Hartlep, N. D. (2014). Asian (American) model minorities. Studies on Asia, 4(1), 1-6.

Hamamoto, D. Y. (1994). Monitored peril: Asian Americans and the politics of TV representation. Minneapolis: University of Minnesota Press.

Ho, P. (2003). Performing the "Oriental": Professionals and the Asian model minority myth. Journal of Asian American Studies, 6(2), 149-175.

Iadicola, P. (2008). Globalization and empire. International Journal of Social Inquiry, 1(2), 3-36.

James, J. (2012, June 13). Orientalism inverted. The Wall Street Journal. Retrieved from http://www.wsj.com/articles/SB10001424052702303768104577460802152339094

Kaibara, H. (2014). The transpacific origins of the "model minority" myth of Japanese Americans. Studies on Asia, 4(2), 5-34.

Kalb, D. (2006). From flows to violence: Politics and knowledge in the debates on globalization and empire. Anthropological Theory, 5(2), 176-204.

Kia, N. (2007). Asian Americans' experiences of "race" and racism. In H. Vera \& J. R. Feagin (Eds.), Handbooks of the sociology of racial and ethnic relations (pp. 131-144). New York: Springer.

Kim, E., \& Aquino, K. C. (2015). Thwarting or embodying model minority stereotypes: An alternative look at adjustment. In N. D. Hartlep (Ed.), Modern societal impacts of the model minority stereotype (pp. 155-184). Hershey, PA: IGI.

Kwon, H., \& Au, W. (2010). Model minority myth. In E. W. Chen \& G. J. Yoo (Eds.), Encyclopedia of Asian American issues today: Volume 1 (pp. 107-110). Santa Barbara, CA: ABC-CLIO.

Lyndon Johnson's "Great Society." (n.d.). U.S. history: Pre-Columbian to the new millennium. Retrieved from http://www.ushistory.org/us/56e.asp

Loomba, A. (2015). Colonialism/postcolonialism. New York: Routledge.

Maddux, W. W., Galinsky, A. D., Cuddy, A. J., \& Polifroni, M. (2008). When being a model minority is good...and bad: Realistic threat explains negativity toward Asian Americans. Personality and Social Psychology Bulletin, 34(1), 74-89.

Maira, S. M. (2009). Missing: Youth, citizenship, and empire after 9/11. Durham, NC: Duke University Press.

McLeod, J. (2010). Beginning postcolonialism. Manchester, UK: Manchester University Press.

Memmi, A. (1965). The colonizer and the colonized. New York: Orion Press. 
Migrant crisis: Migration to Europe explained in seven charts. (2016, March 4). Retrieved from http://www.bbc.com/news/world-europe-34131911

Ono, K. A. (Ed.). (2005). Retracing an intellectual course in Asian American studies. In K. A. Ono (Ed.), A companion to Asian American studies (pp. 1-14). Oxford, UK: Blackwell Publishing.

Okur, M. A. (2007). Rethinking empire after 9/11: Towards a new ontological image of world order. Perceptions, 12, p. 61-93. Retrieved from http://sam.gov.tr/wp-content/uploads/ 2012/01/Mehmet-A.-Okur.pdf

Osajima, K. (2005). Asian Americans as the model minority: An analysis of the popular press image in the 1960s and 1980s. In K. A. Ono (Ed.), A companion to Asian American studies (pp. 215-224). Oxford, UK: Blackwell Publishing.

Oyserman, D. \& Sakamoto, I. (1997). Being Asian American: Identity, cultural constructs, and stereotype perception. The Journal of Applied Behavioral Science, 33(4), 435-453.

Paek, H. J., \& Shah, H. (2003). Racial ideology, model minorities, and the "not-so-silent partner": Stereotyping of Asian Americans in U.S. magazine advertising. Howard Journal of Communication, 14(4), 225-243.

Petersen, W. (1966, January 9). Success story, Japanese-American style. New York Times Magazine. Retrieved from http://inside.sfuhs.org/dept/history/US_History_reader/ Chapter14/modelminority.pdf

Pieterse, J. N. (2004). Globalization or empire? New York: Routledge.

Sakamoto, A., Takei, I., \& Woo, H. (2012). The myth of the model minority myth. Sociological Spectrum, 32(4), 309-321.

Said, E. W. (1978). Orientalism. New York: Vintage Books.

Said, E. W. (1985). Orientalism reconsidered. Cultural Critique, 1, 89-107.

Said, E. W. (1993). Culture and imperialism. New York: Vintage Books.

Saito, N. T. (1997). Model minority, yellow peril: Functions of foreignness in the construction of Asian American legal identity. Asian Law Journal, 4, 71-95.

Schueller, M. J. (2004). Postcolonial American studies. American Literary History, 16(1), 162175.

Shim, D. (1998). From yellow peril through model minority to renewed yellow peril. Journal of Communication Inquiry, 22(4), 385-409.

Smith, N. (2003). American empire: Roosevelt's geographer and the prelude to globalization. Berkeley, CA: University of California Press.

Smith, N. (2005). The endgame of globalization. New York: Routledge.

Steger, M. B. (2005). From market globalism to imperial globalism: Ideology and American power after 9/11. Globalizations, 2(1), 31-46.

Steinmetz, G. (2014). The sociology of empires, colonies, and postcolonialism. Annual Review of Sociology, 40, 77-103.

Taylor, C. R., Landreth, S., \& Bang, H. K. (2005). Asian Americans in magazine advertising: portrayals of the "model minority". Journal of Micromarketing, 25(2), 163-174.

Taylor, C. R., \& Stern, B. B. (1997). Asian-Americans: Television advertising and the "model minority" stereotype. Journal of Advertising, 26(2), 47-61.

The Economist. (2015). The model minority is losing patience. The author. Retrieved from http://www.economist.com/news/briefing/21669595-asian-americans-are-united-statesmost-successful-minority-they-are-complaining-ever 
Thimann, C. (2015). The microeconomic dimensions of the Eurozone crisis and why European politics cannot solve them. The Journal of Economic Perspectives, 29(3), 141-163.

Trytten, D. A., Lowe, A. W., \& Walden, S. E. (2012). "Asians are good at math. What an awful stereotype": The model minority stereotype's impact on Asian American engineering students. Journal of Engineering Education, 101(3), 439-468.

Velasquez, T. G. (2015). From model minority to "angry Asian man": Social media, racism, and counter-hegemonic voices. In N. D. Hartlep (Ed.), Modern societal impacts of the model minority stereotype (pp. 90-132). Hershey, PA: IGI.

Westermann, D. H. (1934). The African to-day. London, UK: International Institute of African Languages \& Cultures.

Wing, J. Y. (2007). Beyond black and white: The model minority myth and the invisibility of Asian American students. The Urban Review, 39(4), 455-487.

Wink, W. (2004). Globalization and empire. Mississippi Review, 32(3), 24-39.

Wong, P., Lai, C. F., Nagasawa, R., \& Lin, T. (1998). Asian Americans as a model minority: Selfperceptions and perceptions by other racial groups. Sociological Perspectives, 4l(1), 95118.

Zakeri, B. H. (2015). A double-edged sword: Side effects of the model minority stereotype on Asian Immigrants in the U.S. In N. D. Hartlep (Ed.), Modern societal impacts of the model minority stereotype (pp. 231-258). Hershey, PA: IGI.

Zhang, Q. (2010). Asian Americans beyond the model minority stereotype: The nerdy and the left out. Journal of International and Intercultural Communication, 3(1), 20-37. 


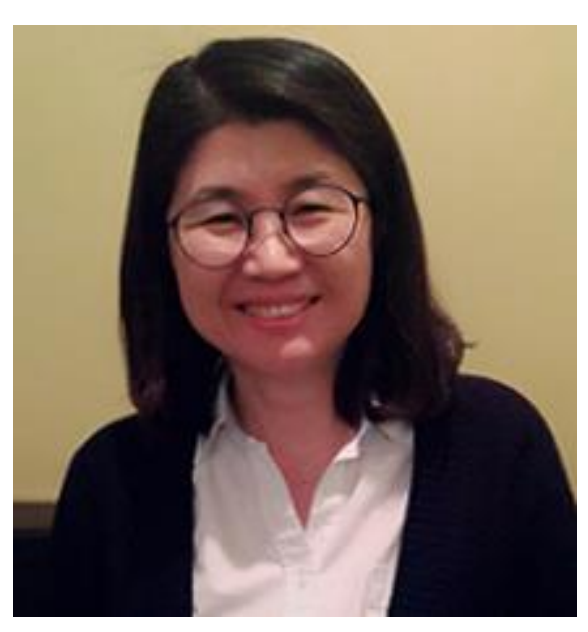

\section{About the Authors}

Eun Hee Kim is a doctoral candidate in Curriculum and Instruction at Kansas State University. She received her M.A. degree in Teaching English as a Foreign Language from the same university and currently teaches in the English Language Program. Her research interests include Asian international students' transnational experience and their perception as prospective immigrants, the model minority stereotype and its impact on Asian students and faculty, ESL teachers' racial and cultural awareness, multiculturalism and humanitarianism in the context of Empire and globalization, and narrative inquiry as a research method. She hopes to reach out to and serve diverse populations both in community and higher education through teaching and research.

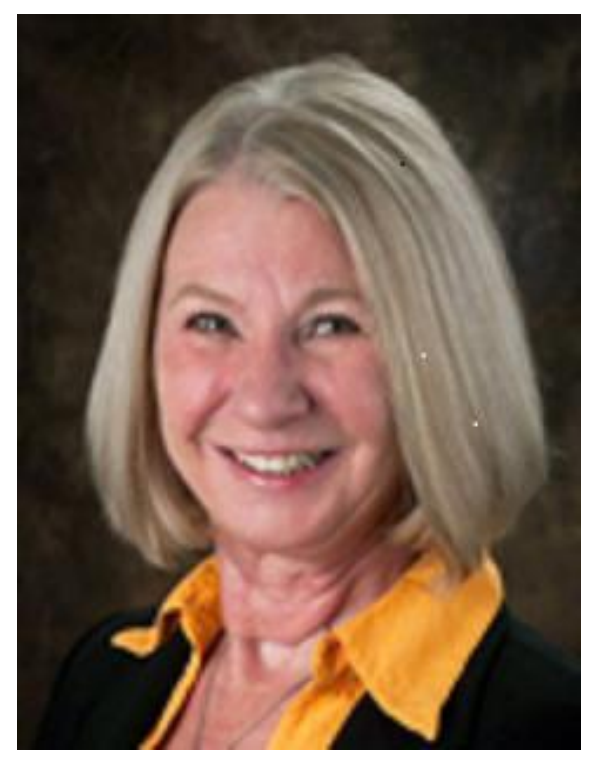

Kay Ann Taylor is an Associate Professor, Department of Curriculum \& Instruction, College of Education; Director, Curriculum \& Instruction Graduate Programs; Associated Faculty, American Ethnic Studies, Kansas State University. Her teaching, research, and service encompass disciplinary intersections that promote social transformation and social justice. Her research interests include history, philosophy, comparative, and sociology of education; biography; critical race theory, critical feminist theories, postcolonial theory, and multicultural issues. Her research is published and presented at national and international conferences. She was the 2009 recipient, Commerce Bank Outstanding Undergraduate Teaching Award, and 2012 recipient, Commerce Bank Presidential Faculty and Staff Award for Distinguished Service to Historically Under-Represented Students, Kansas State University. 


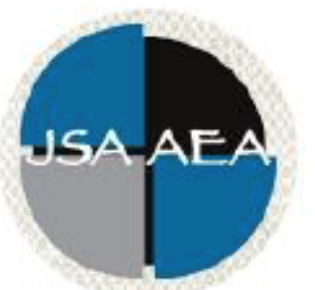

\title{
Journal of Southeast Asian American Education and Advancement
}

Vol.12 Iss.2 Special Issue (2017)

WWW.JSAAEA.org

Special Issue Editor

Dr. Nicholas Hartlep

Metropolitan State University

Editor

Dr. Wayne E. Wright

Purdue University

Associate Editors

Dr. Chhany Sak-Humphry

University of Hawaii at Manoa

Dr. Phitsamay Sychitkokhong Uy

University of Massachusetts, Lowell

\author{
Book Review Editor \\ Dr. Vichet Chhuon \\ University of Minnesota \\ Creative Works Editor \\ Bryan Thao Worra \\ Lao Assistance Center \\ Journal Manager \\ Sung Ae Kim \\ Purdue University
}

\section{Editorial Review Board}

\author{
Dr. Steve Arounsack \\ California State University, Stanislaus \\ Dr. Sovicheth Boun \\ The State University of New York, \\ Fredonia
}

Dr. Carl L. Bankston III

Tulane University

Dr. Angela Reyes

Hunter College, The City University of New York 
Dr. George Chigas

University of Massachusetts, Lowell

Dr. Hien Duc Do

San Jose State University

Dr. Sophal Ear

Occidental College

Dr. Virak Chan

University of Texas at San Antonio

Dr. Jeremy Hein

University of Wisconsin, Eau Claire

Dr. Nancy H. Hornberger

University of Pennsylvania

Dr. Peter Nien-Chu Kiang

University of Massachusetts, Boston

Dr. Ha Lam

Eastern Mennonite University

Dr. Jonathan H. X. Lee

San Francisco State University

Dr. Monirith Ly

Royal University of Phnom Penh

Dr. Bic Ngo

University of Minnesota

Dr. Leakhena Nou

California State University, Long Beach

Dr. Mark Pfeifer

SUNY Institute of Technology

Dr. Loan T. Phan

University of New Hampshire

Dr. Kalyani Rai

University of Wisconsin, Milwaukee

Dr. Cathy J. Schlund-Vials

University of Connecticut, Storrs

Dr. Nancy J. Smith-Hefner

Boston University

Dr. Yer J. Thao

Portland State University

Dr. Monica M. Trieu

Purdue University

Dr. Silvy Un

Saint Paul Public Schools

Dr. Terrence G. Wiley

Center for Applied Linguistics
Dr. Loan Dao

University of Massachusetts, Boston

Dr. Changming Duan

University of Missouri, Kansas City

Dr. Sothy Eng

Lehigh University

Dr. Zha Blong Xiong

University of Minnesota

Dr. Vincent K. Her

University of Wisconsin, Eau Claire

Dr. Peter Tan Keo

New York University

Dr. Kevin K. Kumashiro

University of San Francisco

Dr. Ravy Lao

California State University, Los Angeles

Dr. Stacey Lee

University of Wisconsin, Madison

Dr. Sue Needham

California State University, Dominguez Hills

Dr. Max Niedzwiecki

Daylight Consulting Group

Dr. Clara Park

California State University, Northridge

Dr. Giang Pham

University of Massachusetts

Dr. Karen Quintiliani

California State University, Long Beach

Dr. Phala Chea

Lowell Public Schools

Dr. Fay Shin

California State University, Long Beach

Dr. Christine Su

Ohio University

Dr. Alisia Tran

Arizona State University

Dr. Khatharya Um

University of California, Berkeley

Dr. Linda Trinh Vo

University of California, Irvine

Dr. Yang Sao Xiong

University of Wisconsin-Madison 


\section{Doctoral Student Editorial Review Board}

\author{
Anna H. Yang \\ University of Georgia \\ Annie BichLoan Duong \\ San Joaquin County Office of Education \\ Hoa Nha Nguyen \\ Boston College \\ Malaphone Phommasa \\ Marshall University \\ Molly Wiebie \\ The University of Texas at Austin
}

\author{
Dung Minh Mao \\ University of Minnesota \\ Thien-Huong Ninh \\ University of Southern California \\ Krissyvan Truong \\ Claremont Graduate University \\ Soua Xiong \\ San Diego State University \& Claremont \\ Graduate University
}

